\title{
TITHING IN DEUTERONOMY 14:22-29 AND ITS IMPLICATIONS TO PENTECOSTAL CHURCHES IN NIGERIA
}

\author{
Favour C. Uroko \\ Department of Religion and Cultural Studies \\ Faculty of the Social Sciences \\ University of Nigeria, Nsukka
}

\begin{abstract}
Although Deuteronomy 14:22-29 is understood traditionally in Pentecostal churches in Nigeria to be a call for members of the church to bring their tithes for the pastor's sustenance, this article argues that the theology of Deuteronomy 14:22-29 also includes care and support for widows, orphans, and strangers. It demonstrates that tithing in Deuteronomy 14:22-29 was to be used to improve the life of the poor and needy in ancient Israel. Literature has focused on the reality of paying tithes in Pentecostal churches in Nigeria, but research is scanty on why the number of poor people in Pentecostal churches continue to increase despite that they pay their tithes. It is assumed that understanding tithing in Deuteronomy 14:22-29 will speak anew to the challenge of the neglect of the poor and needy in Pentecostal churches in Nigeria. The pericope reveals that God has a special concern for the poor and that all are called to provide for the poor and the needy.
\end{abstract}

Keywords: Poverty and the Poor; Tithing; Widows; Orphans; Strangers; Refugees; Strangers

\section{Introduction}

Many pastors in Pentecostal churches today have found ways to meet to their personal and family needs. They devise several strategies to raise money such as compelling members to pay their tithes (Nwachukwu 2017), give offerings (Facsar 2018), and make donations (Rotimi, Nwadialor, \& Ugwuja 2016). Members of Pentecostal churches in Nigeria also are willing to give their money, property, and time to meet the needs of the pastor, so that the pastor could pray to God to help the tithing member overcome the challenges of life. Many of these pastors continue to live flamboyant lifestyles with the derivatives from their members, while the members continue to wallow in extreme and abject poverty and in depression. Consider, for example, a Nigerian pastor who builds a school with the tithes of poor congregation members who cannot afford to send their children to those schools (Olarinde 2018); or a Nigerian pastor who buys a private jet for their travel purposes and defends the action with the saying that "poverty is not part of God's plan for man (sic)" (Oladipo 2011). Pastors use such sayings to convince the needy, orphans, and widows who wallow in abject poverty not to relent in bringing their tithes to church. Meanwhile, concerned church members and faith communities turn to biblical perspectives as they seek to discern ways that the needy could be cared for in these Pentecostal churches. 
To assist the concerned church members and faith communities, this article will explore the role of tithing in Deuteronomy 14:22-29 in relation to the needy members of Pentecostal churches in Nigeria. The pericope presents God's instruction to the Levites on how tithes should be used. ${ }^{1}$ Tithing was an integral part of the social system that was established by the Mosaic laws (Moretsi 2004:15). Whether recalling past events, presenting theological arguments, or proclaiming laws, the pericope goes beyond the immediate subject of bringing tithes to the Levites to point out its religious and ethical implications and to call for faith and obedience (Sarna 1989). Deuteronomy 14:22-29 presents divine commands about using tithes for the poor. This article, therefore, employs rhetorical analysis to study how the pericope persuades readers to conform to the truth of proper usage of tithe. According to Obiorah (2015:93), a rhetoric approach analyses the textual strategies by which the communicative aims were achieved in the original situation and are achieved in relation to subsequent readers. The modus operandi of rhetorical criticism is that the biblical texts reveal the context of the author and reader. Thus, Deuteronomy 14:22-29 contains rhetorical statements and words which are of hermeneutical concern to contemporary tithing principles in Pentecostal churches in Nigeria.

Literature has focused on the reality of paying tithes in Pentecostal churches in Nigeria (Ajah 2006; Kitause \& Achunike 2013; Ugwu 2019; Ehioghae 2012), but literature on why the poor in Pentecostal churches continue to increase is scanty. It is assumed that a hermeneutical study of Deuteronomy 14:22-29 will speak anew to the problem of the neglect of the poor and needy in Pentecostal churches in Nigeria. First, this article provides an understanding of Deuteronomy 14:22-29. Second, it explores tithing in Pentecostal churches in Nigeria. Thereafter, the relevance of the pericope to the contemporary tithing principles in Pentecostal churches in Nigeria is sketched.

\section{A Study of Deuteronomy 14:22-29}

The text of Deuteronomy will be considered in its remote and immediate context.

\section{Remote Context}

Moses delivered his final series of addresses during the final months of his life while the Israelites were encamped on the plains of Moab, east of the Jordan river (Hale 2007:390). Before this time, the Israelites had gained victory over the Amorites and Midianites and were on their way towards possessing Canaan. Moses had to repeat these laws given in the books of Exodus, Leviticus, and Numbers, because the Israelites who first heard these laws (on Mount Sinai) had perished in the desert. Thus, Moses had to repeat the laws to teach the new generation of Israelites the ethical lifestyle they were to imbibe when they entered the land. In other words, he was re-emphasising the terms of the covenant on Mount Sinai.

During this period, the children of Israel temporarily settled in the plains of Moab, opposite Jericho and on the threshold of the Promised Land (Chianeque \& Ngewa 2006). One of the principal means by which God had revealed himself is in the historical events of Israel as a community of faith which they needed to recognise as divine (Wright \&

1 It is worth noting that God was interested in meeting the needs of the Levites (Chianeque \& Ngewa 2006:230). 
Fuller 1960:9-10). To the people of Israel on the plains of Moab, these acts made up the constellation of mighty deeds that Yahweh had displayed before them and on their behalf from the days of the patriarchs to their present time in Moab (Zuck 1991:63). The emphasis of the ethics God laid on them concerned Israel's total allegiance to God, which would cause them to prosper in the land given to them. The Israelites had crossed to the other side of Jordan and Moses taught them the commandments of the Lord. Thus, the teaching character of Deuteronomy in effect began the process of transmitting and interpreting the story of God's way with the people (Mays 1982:8). Moses told them how God moved them from Horeb to the mount of the Amorites unto the land of the Canaanites. According to Moses, that was the land that the Lord had reserved for Israel's possession. However, they would be removed from the land and cursed if they disobeyed God (Hale 2007:390).

Moses reminded them of how the Lord guarded them through Ar and Moab, among other cities, and how his mighty power was shown. Deuteronomy was a reminder of God's grace in the past, which meant that, in turn, the people of Israel were called to be thankful and obedient (Mays 1982). This obedience encompasses love-love of the people for God and love of God for the people (Hale 2007). Moses reminded them that for God to continue to keep them they had to obey all the commandments of the Lord (Deut. $4: 1 ; 5: 1 ; 8: 1)$. There is also a repetition of the commandments in Exodus 20 in Deuteronomy 5 . The first three chapters recapitulate what transpired in the preceding book.

\section{Immediate Context}

The laws for tithing are adapted to Israel's new situation in Canaan (see Lev. 27:30-34; Num. 18-21-24; Hale 2007:414). The people of Israel were called the Elect; hence, they were to regard themselves as a family and care for each other. Thus, richer Israelites were expected to help their poorer brethren, and the people of Israel were called upon to bring their first produce to Yahweh. The underlying purpose of encouraging tithing was Yahweh's way of making the people of Israel to care for one another especially the poor among them. Moses spelled out the commandments of God to the people. From vv.1-21, the theme was that of dietary laws - what type of food, how it should be eaten and where and when it should be eaten were spelled out. The dietary rules in Deuteronomy 14:1-20 form part of the ethics of Deuteronomy (Venter 2002:1240). According to Von Rad (1966:102), the Deuteronomic writer employed catalogues which "were no doubt drawn up by the priests at the sanctuaries". In v.22, the theme moved from dietary obligations to tithing. Deuteronomy 14:22-29 "continues the regulation of sacrifice and worship but does so in terms of tithing" (Miller 1990:130).

In vv. 22-23, Yahweh calls on all Israelites to pay their tithes beginning from the agricultural produce. Israelites were also told about the environment in which the tithes should be consumed. They were being groomed to show total recognition of and humility towards the instructions from Yahweh. This practice is evident in Gen 28:22 where Jacob promised God that he would pay his tithe, "Of all that you give me I will give you a tenth" (Chianeque \& Ngewa 2006:230). The tithing law requires that Israelites in all regions donate their tithe locally, which is then eaten by the poor rather than the offeror, in a meal that is secular rather than cultic. Tithe, in this context, goes beyond the 
cultic place and the annual tithe laws by providing charity not only to the local Levite but also to the resident alien, the orphan, and the widow (Mattison 2019:129).

From v.24, the wealthy Israelites were called upon to sell their agricultural produce if the quantity was too large to be moved to the temple. Yahweh pointed out that He was the one who blessed the works of their hands (v.24b). The Levites were to be a major partaker of the tithes received. Money given to the Levites served as salaries or allowances and should be taken as money given to God (Chianeque \& Ngewa 2006:230). The strangers, fatherless, and the widow were also to be beneficiaries of the tithes that were received (v.29) and God expected all Israelites to obey these commandments of tithing. The grounds for demanding obedience are the saving acts that God performed by freeing the Israelites from Egypt, guiding them in the wilderness, and protecting them from their enemies. Thus, tithing was an ancient practice that acknowledged Yahweh's ownership of Israel— the land (Blenkinsopp 2000:102)

\section{Presentation of the structure of Deuteronomy 14:22-29}

The research adopts the structure outlined by scholars such as Mays (1982) and Sherwood and Cotter (2002). The first part is vv. 22-23, the second part is vv. 24-27 and the third part is vv. 28-29.

\section{Produce and Livestock Tithe (vv. 22-23)}

The tithing laws in vv. 22-23 are termed apodictic laws (Thompson 1974:25). Apodictic laws are general commands such as "Thou shall not" which signified divine rebuke and prohibitions. ${ }^{2}$ Hale $(2007: 414)$ states that the laws are adapted to Israel's new situation in Canaan (see Lev. 27:30-34; Num. 18:21-24). In v. 22, God told the Israelites:

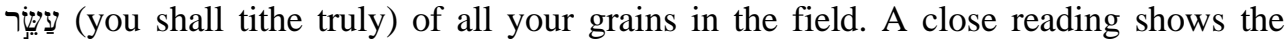
repetition of the Hebrew word 'aśśêr, which means tithe, a tenth, tithe-paying, among others. The repetition shows that tithing should be carried out with honesty and faithfulness by all Israelites. McBride (1987) clarifies that the repetition implies that it is part of sacral dues. In v. 23, וֹאָכָלָָ (and you shall eat) was used to show that tithe is to

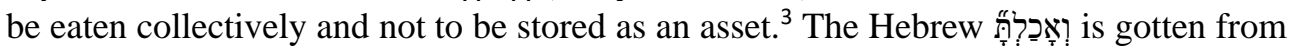
the word אָ (to eat] $)^{4}$. In the context in which wa' ākaltā was used, it meant to eat freely, consume together, and to feast. This entailed that the tithes from agricultural produce (plants and animals) be brought to the temple and eaten by both the poor and the rich in the assembly. The Levites, widows, orphans, and aliens were invited for the meal (Braulik 1999:335). This is prescribed as the greatest feast of the Jewish year and was held in connection with the harvest thanksgiving (Braulik 1999:334). The thanksgiving feast attracted an assembly of worshippers (Matt 16:18; 18:17; Brodie 1992:699).

2 According to Weinfeld (1973:63), a distinction needs to be made between apodictic and casuistic laws in ancient Israel. The origin of the casuistic law is traced to the Canaanite milieu while the apodictic law is the product of genuine Israelite tradition.

3 Black and Rowley (1976:277) observe that this is a sanctuary feast which meant feasting, revelry, and strong drink, but at once the limit is imposed. Such feasts must include worship after which the less privileged are apportioned food and other items according to their needs.

4 Holladay (1988:14) considers animal (Gen. 40:17). Additionally, it is used in a cultic sense about an offering or sacrifice (Deut 12:7). 


\section{Commuting to cash (vv. 24-26)}

In v. 24, God instructed the Israelites to sell their material tithes and convert it to money

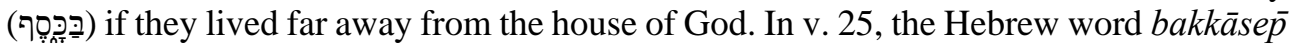
was also used to indicate converting material tithe to money/silver and the monetary exchange was to be brought to the house of the Lord. The Hebrew (for money) is derived from כֶֶֶ (money, silver). God instructed the people that if their agricultural produce was too much to carry or if they considered the distance too long between where the produce was and the temple, they should sell the produce and bring the money to the temple (v.24). This is otherwise called the 'deconsecration' of the tithe (Mt. 14.24-26; Rofé 1985:25). Chianeque and Ngewa (2006:209) note that the option of converting goods into money was the justification for the sale of animals in the temple to which Jesus objected so strongly.

\section{Assignment of tithes to the helpless (vv. 28-29)}

The term (the Levite) is mentioned in relation to those who should be part of the recipients of the tithes. The Levites had no source of income and paying tithes to them was a means of encouraging them in their ecclesial work. The Levites were the descendants of Levi and were the "anointed" (Werman 1997:211). They served as both priests and those who gave religious instructions (Emerton 1962; Weinfield 1967). Apart from the Levites, v.29 mentions that the tithes should also be shared to the

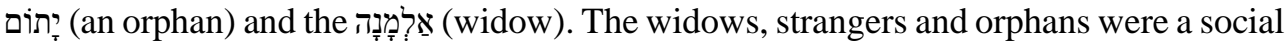
subgroup and belong to a category of underclass, socially weak persons in ancient Israel (Bennett 2002:23). The problem between the three groups is a socio-economic one. Their socio-economic status places this group as the most vulnerable to starvation in the society. The $\mathrm{z}$ is a sojourner ${ }^{5}$ who was forcibly displaced from his original abode. The ר immigrated into a new place without socio-political protection or privilege in the different host community. The comprised mostly of those displaced by famine, war,

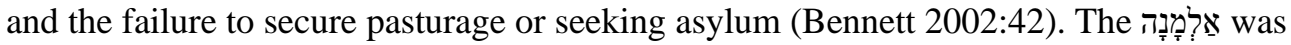
a woman who lost her husband and was liable for the economic debts left by her husband. The ית is one who had lost the parents. Bennett (2002:49) defines an orphan as one who is fatherless or without parents and who see God as their protector. The Levite, the stranger, the orphan, and the widow ${ }^{6}$ were dependent on the community for their welfare. Craigie (1976) asserts that the system of tithes enabled the Israelites to learn and understand their continual dependence on God. Israelites gave their money, crops, and material possessions to God. They strongly believed that God made the provision in the first place; and they learned to remember that the source of their substance was God (Craigie 1976:234).

Israelites did not see tithing as a burden. They saw it as a way of expressing their love for and trust in God, basing their actions on the fact that God had promised to bless the works of their hands (Deut. 14:29). Tithing was a way of expressing gratitude to God who made their produce to increase (Moretsi 2004:15), and it was a practice ordained by God who made it clear that tithing should be used to care for the Levites, the stranger,

5 Kohlenberger (1987:527) sees the as also an alien who was not part of the community of Israel. They have no home or people to stay with.

6 Blenkinsopp (2007:102) sees them as the disadvantaged (Deut. 26:12-15; Lev. 27:30-33; Num. 18:21-32). 
the orphan, and the widows. Henry (2006:255) asserts that God cares for the widows and fatherless. This group of people was taken as the poorest in the church. It is important therefore to present the situation of the strangers, orphans, and widows in Pentecostal churches in Nigeria in the light of the usage of tithes.

\section{The concept of tithing}

Tithing could be defined as the offering of one-tenth of one's income, which may be money or material things. The tithe therefore is one-tenth of one's income. Tithing honours the scriptural principle of generously providing for the church. Religious leaders and the needy are perceived to have no other source of income and no one to provide for them. Tithe in the sight of many believers is the minimum of what they want to give to God, which is given to the church because it is believed to be the house of God (Jambrek 2007). The church is the community of believers having a leader who presides over activities of the group. These leaders put their trust in the church for their upkeep and well-being.

Novaković and Punda (1995) note that supporting God's servants and the needs of the congregation are the reasons for the collection of tithes. Although the proceeds from tithes are meant to provide for God's servants, the needy also are supposed to benefit from them. Howbeit, payment of tithes is not by coercion, but by conviction. According to Budiselić (2014), church members are encouraged to give with no coercion or legal obligation to give a tenth of their gross income. However, Kelly (2007) asserts that tithe is one-tenth of one's income which is given for the benefit of a religious organisation (pastors and ministers, the poor widows) and may be done through legal coercion.

The idea of tithing, as an ancient practice, was meant for the care of the priests and the needy in the society. This is because money from tithe is used to pay church workers for mission work, church debts, and for social programs. Tithe, according to Most Rev. Dr Alfred Adewale Martins, is used for church maintenance (Irekamba 2019). Pastor Lazarus Muoka, the General Overseer of the Lord's Chosen claimed that tithe is used for church members' welfare. Irekamba (2019) explains that church members' welfare includes the care and rehabilitation of penitent prostitutes and ex-prisoners; establishment of armed robbers who gave their lives to Christ as well as of kidnappers that have resolved to stop their selfish act; and the care of widows and orphans who are needy (Irekamba 2019).

\section{Pentecostal churches and tithing in Nigeria}

Some Pentecostal churches view tithe as "an ancient Judeo-Christian practice, which is based on the biblical mandate to support the work of religious organizations and to care for those in need" (Boddie 2019:1). Pentecostal churches in Nigeria are characterised by "teachings on faith, tithing prosperity, miracles, evangelism, and speaking in tongues" (Gaiya 2002:1). It is believed that tithing makes God bring prosperity and miracles to the members of the Pentecostal churches in Nigeria. However, Pentecostal churches in Nigeria also teach that one who is born again must be able to speak in new tongues. They also believe in spiritual warfare through prayers and other rituals such as casting out demons and so forth. Marshall (1993) calls this characteristic, a 'born-again ethics.' $\mathrm{He}$ also notes that these are the reasons that several thousands of Pentecostal churches are found all over Nigeria. Meyer (1995) adds that Pentecostals have reinvented the 
Tithing in Deuteronomy 14:22-29 and its Implications to Pentecostal Churches in Nigeria 7 categories of power and status which were initially associated with material wealth and political connection in relation to revelation and spiritual authority.

Based on revelation and spiritual authority, Pentecostal pastors often admonish their members to pay tithe as a spiritual obligation. They cite various texts from the Torah which emphasise the spiritual condemnation of defaulters of tithe paying. For instance, on 16 July 2020, Bishop David Oyedepo of Living Faith Church warned his members, saying, "You're under financial curse if you don't pay tithe" (Eniola 2020:1). The statement generated mixed reactions from Nigerians. Pastors of Pentecostal churches often tell their members that power and blessings are available and could also be mediated to the faithful by the anointed man or woman of God who receives the tithe (Hackett 1998). The members act according to the dictates of the pastor to not to provoke God or go against his injunction. Generally, this tithe is calculated as an actual one-tenth of a church member's income.

\section{Features of tithing in Pentecostal churches in Nigeria}

The features of tithing in Pentecostal churches include but are not limited to the undermentioned.

\section{Sole proprietorship}

Some Pentecostal churches in Nigeria reputably belong to a single person or family. This means that the tithes collected are remitted to the founder/general overseer for personal and family consumption. If only one person is in charge of handling money, that could lead to fraud, but that is what obtains in some Pentecostal churches in Nigeria. Some pastors pay armed bodyguards and other church officials such as secretaries, personal assistants, protocol officers and others from the people's tithe (Adenugba \& Omolawal 2014). This is to show how financially buoyant they are even though this is at the expense of the tithe payers.

\section{Monitoring through registration cards}

Registration cards are used by these churches to ensure that no member escapes paying tithe. Unfortunately, these cards are used by the founders of the churches to monitor how much salary their members earn. ${ }^{7}$ In the monitoring process, the person who is observed to pay a big tithe is given special treatment such as a special seat in front of the church (Mutebi 2013). Members who pay little tithe, on the other hand, are treated with disdain and all their actions are offensive to the pastor. The pastors use these cards to monitor members' earnings; but the sad thing is that when you are broke, the church still expects you to contribute money because the leaders already know how much you earn, and when you refuse, you are seen as one who tries to hinder the work of God (Mutebi 2013). The pastor then begins to attack the erring church members and prevents them from getting certain privileges.

7 Esther, "Oral Interview," in Warri Delta State on May 12, 2019 and a member of the Greater Evangelistic Ministry 


\section{Winning respect and commendation}

Members who pay tithes in Pentecostal churches receive much respect from their pastors and founders. For example, the Living Faith Church and the Redeemed Christian Church of God (RCCG) recognise their members based on the tithe/or tithe booklet. In RCCG, those paying tithes dance with their envelope to the altar and the pastor recognises their face notwithstanding whether their heart is right with God or not. This makes the paying of tithes a fun-fair (Sean 2019). Furthermore, in some Pentecostal churches such as Greater Evangelism World Crusade and the Assembly of God Church, ushers hand out envelopes or tithe envelopes and cards, and on the envelopes are spaces to write one's name, the amount one is giving and the contact details. ${ }^{8}$ Particularly, in the Assembly of God Church, a gift is given to the highest tithe payer. His or her name and the amount paid are announced in the church while people clap for the person.

\section{Praying for payers of tithes}

Tithe payers are asked to come out with their tithe book for prayers before dropping their tithe in the tithe box. However, poor people who do not have money to pay tithe are neglected spiritually and physically. The officiating pastor usually asks other people in the church to stretch their hands towards those who are standing at the altar with their tithes and pray for them.

\section{Special Responsibilities}

In some Pentecostal churches, special responsibility is given to church members based on the amount of tithe they pay. This includes appointing tithing members to positions of pastor, elder, deacon, assistant pastor, and Sunday school teacher, etcetera.

\section{Impact of tithes in Pentecostal Churches in Nigeria}

The impact of tithes on church growth and development cannot be overemphasised, and this will be discussed under two sub-headings.

\section{Tithes and the members - Negative relationship}

The cry of the oppressed in some Pentecostal churches is worth noting here. In most Pentecostal churches, believers are urged to make offerings to the church (in addition to paying tithes), submit themselves to fasting and other religious disciplines, and pray wherever they are, be it at home, in the market or at work (Sean 2013). In some sermons, Christians are reminded that their relationship with God would be verified through tithes paid to their church and special donations which would unlock the heavens for them (Meyer 2007). There is this emphasis on the exchange or bargain between man and God. Some pastors emphasise that God will only bless a person who gives unconditionally through tithing to God. Meyer (2007) laments that the affirmation that giving to God will provide divine blessings, of course, is reminiscent of the contract with the devil in which a person involves him/herself in an exchange relationship with an invisible power to become rich.

The belief is that the future is saleable and that one's tomorrow could be bought (Otabil 2002). Hence, tithe is placed as the monetary means of exchange in the buying

8 Victoria, "Oral interview," a member of the Assembly of God Church, Port Harcourt Nigeria. 
euphoria. Meyer (2007) writes that most of these Pentecostal churches are still surviving because of the financially successful members who support them through tithe paymentthey attract these rich people through healing and power-over-wicked-people sermons. Unfortunately, most of these believers continue to live in poverty even though they are born again. When the expectation of material signs that are promised with the paying of tithes fails, the person is blamed for the failure. Regarding the happy few living in affluence, the question is whether their wealth truly signifies divine blessing (Meyer 2007). The beliefs, morals and values on which church ethics is supposed to be built are ignored (Freeman 2012). Pentecostalism is considered one of the faith communities of the poor; and the poor pay their tithe freely with the belief that their condition will change. Jacobs et al (2014:1) lament thus:

They are reminded daily that givers never lack. In a bid to please "God" and achieve the elusive breakthrough parishioners squeeze themselves dry to contribute to various projects in the house of God. But surprisingly their situation never changes. The more they give the poorer they become and the richer the church. Today's church is an epitome of modernity operating from state-of-the-art, imposing edifices fully air-conditioned and complete with evolutionary camera, klieg light and other stage facilities for live broadcast from the pulpit. Yet poverty ravages the same establishment.

No one wants to remain in a poor state for long. Hence, the poor see tithing as a way of pushing God to change their situation. Premawardhana (2012) and Maxwell (1998) argue that the aggressive solicitation of tithes from largely uneducated congregants is pure exploitation. The maxim in the mouth of the pastors is, "The more you give to God, the more God blesses you". Therefore, some poor church members go to great length to borrow money to pay tithes to please their pastors. Many widows, orphans, strangers, and the poor also continue to live in abject poverty and debt despite paying their tithes while their pastors continue blatantly to live flamboyant lifestyles.

\section{Tithes and ministers-Positive relationship}

The rate at which Pentecostal churches are being established throughout Nigeria may be since tithes and offerings are formidable ways of making quick money. Many men and women who went into business and failed decide to establish churches, insisting that God called them by making their business to fail. They emphasise in their sermons that tithe is God's way of preserving his servants. Some of these pastors grow fat physically and financially, thanks to the many fat tithes from poor members which are diverted into their private pockets by coercion, persuasion, and compulsion. . It is common to see pastors living flamboyant lifestyles and in expensive clothes, cars, and even private jets while their members wallow in poverty. These pastors convince their congregation that their God is not a poor God, a cliché that has earned them the name, preachers with sugar-coated tongues (Adenugba \& Omolawal 2014). The gross materialism and extreme economic liberalism of the current Pentecostal movements in Nigeria are daily crushing the poor. Expensive churches harbour very rich pastors whose mark of success are mansions, flashy cars as well as expensive dresses, shoes, wristwatches and pieces of jewellery, the costs of which can feed thousands of hungry followers (Adenugba \& 
Omolawal 2014:526). The British Broadcasting Corporation (2013) sees these pastors as businessmen and women whose wealth can be compared to that of oil barons.

The pastors frequently assure members of their church that they would be rich or without ailment once they continually pay their tithe (Ukah 2008). Thus, through coercion and compulsion, they ensure that members pay their tithes regularly, even if they must borrow to do so. Fagbamila and Abdulganiyu (2014:12) point out that:

They ride in posh cars and own massive mansions . . . while members of their congregation wallow in abject poverty. Regardless of the mighty cathedrals and imposing mansions, members of the congregation whose money was used to erect the imposing structures still live below the poverty bracket ... The only doctrine and scripture consistently held unto by religious leaders is the version of the holy book which says: give and it shall be given unto you, in good measures, press down, shaking together shall men give unto your bosom.

These Pentecostal churches are sited in the city because it is believed that God loves the city and has plans for the good of the city (Ogbu 2000:129). Furthermore, the churches choose mainly urban centers to deal with the rising level of frustration, unemployment, and crime in such settings (Ogbu 2000:129). The belief is that "rural environments and country sides represent the domain of malevolent spirits and forces such as witches, wizards, demons, and sorcerers" (Probst 2004:416).

\section{Application of the text in the Nigerian context}

Deuteronomy 14:22-29 recommends that tithes for Levites should be brought to the temple as the Levites were sustained with the proceeds of these tithes. The Levites were not engaged in any other assignment than to make people understand the law of God (Douglas 1994:291). In the Nigerian context, some pastors and ministers of God who are in full-time ministry have no other means of livelihood just as the Levites in Israel. However, many full-time pastors engaged by the churches earn as low as N25,000 per month, while some only receive recharge cards for their phones at the end of the month (Alex 2017). The Israelites, on the other hand, were to use the money they got from goods sold to buy food and drink to be consumed before the Lord. It was a celebration of the increase in farm produce. The widows, orphans, and strangers also benefitted from these tithes. In ancient Israel, those three groups lacked socio-economic resources. Coggins (1987:12) notes that widows, orphans, and strangers were particularly mentioned by the Deuteronomists because of their condition. The pericope made it clear that God has a special concern for the poor and that all are called to provide for the poor and the needy (Chianeque \& Ngewa 2006:230). God gave this instruction because, in Canaan, the Israelites experienced wealth in abundance, but they had to remember the desert experience and the liberation from slavery in Egypt as the basis of their existence. These events should motivate them to keep the Mosaic Law (Scheffler 2013).

In Nigeria, the tithe is used only by the pastors and their families. The poor are told that God is not a poor God hence those who expect to experience breakthroughs, exit poverty and regain their health should continually bring in their tithe (Tazanu 2016:35). Widows clearly need support, but the church has stopped supporting the poor (Sossou 2002). The church is the last hope of the common man and has the divine obligation to 
Tithing in Deuteronomy 14:22-29 and its Implications to Pentecostal Churches in Nigeria 11

help the poor and the underprivileged (Kwarteng \& Acquaye 2011). Unfortunately, some Nigerian Pentecostal pastors have ignored this obligation with their emphasis on tithe paying to meet their selfish desires. From the perspective of Deuteronomy 14:22-29, tithe was for the care of the poor and needy in Israel (Levites, widows, orphans, strangers) (Corey 2009). In Nigeria, however, tithe is spent at the sole discretion of the founder or general overseer of the church who dictates how, when, and where the collected tithe should be spent but who continues to grow financially stronger at the expense of the tithes payers. From the above thesis, one wonders why some pastors in Pentecostal churches in Nigeria refuse to follow the instruction of God to care for and support the Levites, widows, and orphans. In the light of Deuteronomy 14:22-29, the following suggestions may help pastors and faith communities in caring for their needy church members.

\section{Defining the roadmaps}

The following are recommendations regarding how to use tithes to transform the lives of the poor in Pentecostal churches.

1. Pentecostal churches in Nigeria should devise a strategy for identifying the poor amongst them. This could be done through the creation of a welfare committee that is responsible for identifying the poor, widows, orphans, and strangers in their midst.

2. The rich members of the church are encouraged to give generously to those they perceive to be poor in their midst. This may be done on an individual basis.

3. Notwithstanding that most pastors of Pentecostal churches have no other jobs besides ministering, they should exercise discipline in administering the tithes brought to the church.

4. Pastors and general overseers should not insist that tithes be paid directly to them. It may lead many pastors into greed and open the way for them to compromise their religious standing.

5. Pentecostal churches should see poverty eradication and alleviation as part of the Great Commission by God and Jesus Christ. Through care and support to the needy, the gospel is spread at a faster pace and dimension. Part of the poverty eradication strategy would be to give soft loans to the needy that would enable them to start their own businesses.

6. Pentecostal churches should have a welfare department where there will be a 'food bank', 'money bank' and 'miscellaneous bank' for indigent church members. Jones terms this strategy 'storehouse tithing' (Jordon-Jones 1992).

7. There should also be job training and empowerment programmes for this group of needy people in the church.

\section{Conclusion}

Tithe should be used for the care of the Levites (pastors) and the poor in the church. It is not the sole prerogative of pastors to reserve tithes brought to the church for their 
personal use. The traditional norm in Pentecostal churches in Nigeria where the poor are neglected is denounced in Deuteronomy 14:22-29. The grammatical-theological analysis of Deuteronomy 14:22-29 prioritises the care and support of the poor in Israel through the tithes brought to the temple. The people were encouraged to sell their goods and bring the proceeds from the sale to the temple. In the pericope, the emphasis is on the beneficiaries of the tithe such as the Levites, the widows, strangers and the orphans. Lessons from this pericope are projected as worthy of emulation by Pentecostal churches in Nigeria. This is because some Pentecostal churches in Nigeria are organisations which are individually owned and administered. This has given room for greed and priestly hubris to the detriment of the church followers. It is advised that tithes should be used to transform the lives of congregation members. In this way, others join in caring for the poor just as in ancient Israelite society. Pentecostal pastors are to stop using tithe for their personal benefit but are encouraged to consider the needy also.

\section{BIBLIOGRAPHY}

Adenugba, A.A. and Omolawal, S.A. 2014. Religious values and corruption in Nigeria: A dislocated relationship. Journal of Educational and Social Research 4(3): 524.

Adeyemo, T. 2006. Discipleship. In Adeyemo, T. (ed.), Africa Bible Commentary: A one volume commentary written by 70 African scholars. Nairobi: Word Alive.

Ajah, M. 2006. Tithing in Ugarit and the Pentateuch: Possible implications for Africa. Scriptura: International Journal of Bible, Religion and Theology in Southern Africa 91 (9): 31-42.

Alex, R. 2017. Nigeria: Salary structure of mega church pastors. Available online: https://www.nigerianbulletin.com/threads/nigeria-salary-structure-of-megachurch-pastors.232470/ (Accessed on 12 March 2019).

BBC. 2011. Nigeria's pastors as rich as oil barons. Available online: https://www.bbc.com/news/world-africa-13763339 (Accessed on 4 March 2019).

Bennett, H.V. 2002. Injustice made legal: Deuteronomic law and the plight of widows, strangers, and orphans in ancient Israel. Grand Rapids, MI:Wm. B. Eerdmans.

Black, M. and Rowley, H.H. 1976. Peake's Commentary on the Bible. Nairobi: Thomas Nelson.

Blenkinsopp, J. 2007. Deuteronomy. In Brown, Raymond E., Fitzmyer, Joseph A. and Murphy, Roland E. (eds.), The New Jerome Biblical Commentary. Delran, NJ: Simon \& Schuster, 102.

Boddie, S.C. 2019. Tithing practices that benefit families, congregations, and communities. Available online:

https://openscholarship.wustl.edu/cgi/viewcontent.cgi article $=1457 \&$ context $=\mathrm{csd}$ _research (Accessed on January 25, 2019).

Braulik, G. 1999. The political impact of the festival-biblical statements. Verbum et Ecclesia 20(2):335.

Brodie, T. 1992. Fish, temple tithe, and remission: The God-based generosity of

Deuteronomy 14-15 as one component of Matt 17: 22-18. Revue Biblique 35: 699.

Budiselić, E. 2014. The role and the place of tithing in the context of Christian giving. Kairos 8(2): 145. 
Tithing in Deuteronomy 14:22-29 and its Implications to Pentecostal Churches in Nigeria 13

Corey. Tithing in the Bible: Eating Your Tithe (Deuteronomy 12, 14, and 26), viewed 30 April 2021, from http://www.providentplan.com/795/tithing-in-the-bibleeating-your-tithe-deuteronomy-12-14-and-26/.

Chianeque, L.O. \& Ngewa, S. 2006. "Deuteronomy", in Adeyemo, T. (ed), Africa Bible Commentary, Nairobi: World Alive Publishers, pp. 209-255

Coggins, R. 2013. The Old Testament and the poor. The Expository Times 99(1): 12. Craigie, P.C. 1976. The book of Deuteronomy. Grand Rapids, MI:Wm. B. Eerdmans, 234.

Fagbamila, D.O. \& Abdulganiyu, I.A. 2014. The role of religion in modern society: Masses opium or tool for development: A case study of Saw-mill Area, Ilorin, Kwara State, Nigeria. International Journal of Sociology and Anthropology 6 (1): 12.

Douglas, M. 1994. The stranger in the Bible. European Journal of Sociology/Archives Européennes de Sociologie 35(2): 291.

Ehioghae, E.M. 2012. Tithing and the quest for material prosperity: A critical evaluation of contemporary trends in Nigerian Pentecostalism. Asia-Africa Journal of Mission and Ministry 6: 143-160.

Emerton, J.A. 1962. Priests and Levites in Deuteronomy an examination of Dr. G.E Wright's theory. Vetus Testamentum 12(1): 252.

Eniola, A. 2020. You are under financial curse if you do not pay tithe -Oyedepo. Punch Newspaper, 17 July 2020.

Facsar, F. 2018. Nigerian Pentecostal megachurches a booming business. Available online: https://www.dw.com/en/nigerian-pentecostal-megachurches-a-boomingbusiness/a-45535263 (Accessed 18 September 2018).

Freeman, D. 2012. The Pentecostal ethic and the spirit of development. In Freeman, D eds. Pentecostalism and development. London: Palgrave Macmillan., pp.1-20

Gaiya, M.A.B. 2002. The Pentecostal revolution in Nigeria. An occasional paper presented at the Centre of African Studies, University of Copenhagen. Available online: https://teol.ku.dk/cas/publications/publications/occ._papers/gaiya2002.pdf. (Accessed on 2 March 2019).

Hackett, R. 1998. Charismatic/Pentecostal appropriation of media technologies in Nigeria and Ghana. Journal of Religion in Africa 28(3)263.

Hale, T. 2007. The Applied Old Testament Commentary. Colorado Springs: David C. Cook Distribution Canada.

Henry, M. 2005. Matthew Henry's Commentary on the whole Bible. Peabody, MA: Hendrickson Publishers.

Holladay, W.L. 1988. A Concise Hebrew and Aramaic Lexicon of the Old Testament. Grand Rapids, MI: Williams B. Eerdmans.

Irekamba, C. How do churches utilize the tithe members pay? Available online: https:/guardian.ng/features/how-do-churches-utilise-the-tithe-members-pay/ (Accessed 12 February 2019).

Jacobs, N., Onuegbu, C., Duru, P., Ebirim, J., Edukugho, E. and Anibeze, O. 2014. Rich churches, poor members. Vanguard 25 October 2014.

Jambrek, S. 2007. Desetina. In Jambrek, Stanko (ed.), Leksikon evanđeoskog Kršćanstva. Zagreb: Bogoslovni institut i Prometej, 132. 
Jordon-Jones, M.C. 1992. An exegetical study of the biblical passages cited by the Wesleyan Church regarding storehouse tithing. Masters' thesis, Asbury Theological Seminary, . Wilmore.

Kelly, R.E. 2007. Should the church teach tithing? Lincoln: Writers Club Press.Kitause, R.H and Achunike, H.C. 2013. A historical discourse on tithing and seed sowing in some Nigerian Pentecostal churches. IOSR Journal of Humanities and Social Science 18 (3): 7-19.

Kohlenberger III, J.R. 1987. The InterLinear NIV Hebrew-English Old Testament. Grand Rapids, MI: Zondervan

Kwarteng, C.O. and Acquaye, H.E. The role of Ghanaian churches in the financial rehabilitation of the poor: Implications for re-visiting the social mission of religious institutions. Journal of Financial Services Marketing 15(4): 31.

Marshall, R. 1993. Power in the name of Jesus: Social transformation and Pentecostalism in Western Nigeria revisited. In Ranger T. and Vaughan, O. (eds.), Legitimacy and the state in twentieth-century Africa. London: Palgrave Macmillan, 213-246.

Mattison, K. 2019. Rewriting and revision as amendment in the laws of Deuteronomy. Heidelberg: Mohr Siebeck.

Maxwell, D. 1998. Delivered from the spirit of poverty? Pentecostalism, prosperity, and modernity in Zimbabwe. Journal of Religion in Africa/Religion en Afrique 28(3): 350.

Mays, J.L. 1982. Interpretation: A Bible commentary for teaching and preaching. Louisville KY: John Knox Press, 8-9.

McBride Jr, S. D. 1987. Polity of the covenant people: The book of Deuteronomy, Union Seminary Review 41(3):229- 244.

Meyer, B. 1995. Beyond syncretism: Translation and diabolization in the appropriation of Protestantism in Africa. In Stewart, Charles and Shaw, Rosalind (eds.), Syncretism/anti-syncretism: The politics of religious synthesis. London: Routledge, pp. 1-20

Meyer, B. 2007. Pentecostalism and neo-liberal capitalism: Faith, prosperity, and vision in African Pentecostal-charismatic churches. Journal for the Study of Religion1(1) : 18.

Miller, P.D. 1990. Deuteronomy. Interpretation. A Bible commentary for teaching and preaching. Louisville, KY: John Knox.

Moretsi, L. H. 2004. An exegetical study of Malachi 3:6-12 with special reference to tithing. MTH thesis, North West University Potchefstroom Campus.

Mutebi, B. 2013. To write your name or not on the Lord's money bag. Available online: https://www.monitor.co.ug/Magazines/Life/To-write-your-name-or-not-onthe-Lord-s-money-bag/689856-1983468-wcbdwh/index.html (Accessed on 8 September 2013).

Novaković, M. and Punda, G. 1995. Biblija govori. Zagreb: Crkva cjelovitog Evanđelja.

Nwachukwu, J.O. 2017. Pastor Ashimolowo compels members to pay $\$ 1,000$ dollars for each year they have lived on earth. Daily Post, June 15, 2017.

Obiorah, M.J. 2015. Bibliotheca divina: A basic introduction to the study of the Bible. Nsukka: University of Nigeria Press. 
Tithing in Deuteronomy 14:22-29 and its Implications to Pentecostal Churches in Nigeria 15

Ogbu, K. 2000. Power, poverty and prayer: The challenges of poverty and pluralism in African Christianity, 1960-1996. FrankFurt am Main: Peter Lang. Lark.

Oladipo, T. 2011. Nigeria: Where religion is big business. BBC. Available online: https://www.bbc.com/news/world-africa-14573660. (Accessed 22 August 2011).

Olarinde, I. 2018. Nigerians debate giving 10\% of their income to the church. Available online: https://www.bbc.com/news/world-africa43286733\#:

$\sim:$ text $=\% 22$ You $\% 20$ have $\% 20 \mathrm{a} \% 20$ pastor $\% 20$ who, as\%20a\%20follower\%20of\%20Christ (Accessed on 19 April 2018).

Otabil, M. 2002. Buy the future: Learning to negotiate for a future better than your present. Lanham, MD: Pneumalife Publishing.

Premawardhana, D. 2002. Transformational tithing: Sacrifice and reciprocity in a neoPentecostal church. Nova Religio: The Journal of Alternative and Emergent Religions 15(4): 86.

Probst, P. 2004. Between resistance and expansion: Explorations of local vitality in Africa. 18. Grevener Str.: LIT Verlag Münster.

Rofé, A. 1985. The laws of warfare in the book of Deuteronomy: Their origins, intent and positivity. Journal for the Study of the Old Testament 10(32): 29.

Rotimi, N.C., Nwadialor, K.L., and Ugwuja, A.A. 2016. Nigerian Pentecostal churches and their prosperity messages: A safeguard against poverty in Nigeria? 1980-2014. Mgbakoigba: Journal of African Studies 5(2): 10-22.

Sarna, N. 1989. The JPS Torah Commentary. Philadelphia: The Jewish Publication Society.

Scheffler, E. 2013. Of poverty prevention in the Pentateuch as a continuing contemporary challenge. Verbum et Ecclesia 34(2): 4.

Sean, T. Re: Is tithe card necessary like we can find in my church? Available online: https://www.nairaland.com/3092713/tithe-card-necessary-like-find/2 (Accessed on 4 March 2019).

Sherwood, S.K. and Cotter, D.W. 2002. Leviticus, Numbers, Deuteronomy. Minnesota: The Liturgical Press.

Sossou, M-A. 2002. Widowhood practices in West Africa: The silent victims. International Journal of Social Welfare 11(3): 200.

Tazanu, P.M. 2016. Practices and narratives of breakthrough: Pentecostal representations, the quest for success, and liberation from bondage. Journal of Religion in Africa 46(1): 35.

Thompson, J.A. 1974. Deuteronomy: An introduction and commentary. Downers Grove, IL: Inter-Varsity Press.

Ugwu, B.I. 2019. Tithe and tithing in the Catholic Church in Nigeria today. Ministerium: A Journal of Contextual Theology 2 (2), 1

Ukah, A. 2008. Roadside Pentecostalism: Religious advertising in Nigeria and the marketing of charisma. Critical Interventions 2(1-2): 127.

Venter, P.M. 2002. The dietary regulations in Deuteronomy 14 within its literary context. HTS Teologiese Studies/Theological Studies 58(3), 1240

Von Rad, G 1966. Deuteronomy. London: SCM.

Weinfeld, M. 1973. The origin of the apodictic law: An overlooked source. Vetus Testamentum 23(1): 63. 
http://scriptura.journals.ac.za

16

Werman, C. 1997. Levi and Levites in the Second Temple period. Dead Sea Discoveries 1(1): 211.

Wright, E. and Fuller, R.H. 1960. The book of the Acts of God. Garden City, N.Y: Doubleday.

Zuck, R.B. 1991. A biblical theology of the Old Testament. Chicago, IL: Moody Press. 